\title{
Control of Ascochyta blight of Chickenpea using Essential Oils from Thyme (Thymus vulgaris), Sage (Salvia officinalis L.) and Rosemary (Rosmarinus officinalis L.) Plants
}

Waithaka $\mathrm{PN}^{1^{*}}$, Gathuru EM², Githaiga $\mathrm{B}^{2}$ and Mwaringa $\mathrm{JD}^{2}$

${ }^{1}$ School of Biological Sciences, University of Nairobi, Nairobi, Kenya

${ }^{2}$ Department of Biological Sciences, Egerton University, Njoro, Kenya

*Corresponding author: Waithaka PN, School of Biological Sciences, University of Nairobi, 30197-00100, Nairobi, Kenya, Tel: +2540734074242; E-mail: waithakanj@yahoo.com

Received date: June 19, 2018; Accepted date: July 27, 2018; Published date: August 03, 2018

Copyright: ( 2018 Waithaka PN, et al. This is an open-access article distributed under the terms of the Creative Commons Attribution License, which permits unrestricted use, distribution, and reproduction in any medium, provided the original author and source are credited.

\begin{abstract}
Chick pea is considered as the most important sources of cheap protein. However, the crop is endangered by a number of fungal diseases. Top in the list of these fungal diseases is ascochyta blight. This study was aimed at testing the sensitivity of Ascochyta rabiei to essential oils from thyme, sage and rosemary plant. Infected chick pea plant samples were collected from field seven in Egerton University. Fungal pathogens were isolated from the infected plants. Essential oils were extracted from thyme, sage and rosemary plant. Sensitivity of Ascochyta rabiei against extracted different essential oils was carried out, using agar well technique. The prevalence of Ascochyta rabiei in the plant samples from chick pea was $50 \%$. The most active fungal pathogens were Alternaria spp. (45\%), Aschochyta rabiei (50\%), Fusarium spp. (22\%), and Penicillium spp. (16\%) and Coletotrichum spp. (17\%).

There was a relationship in between yield of essential oils and heating time in rosemary $(r=0.99)$ and leaves $(r=0.99)$. Generally, no significant difference in the \%yield of essential oils thyme, sage and rosemary $(P=0.057)$ was seen. The percentage yield of essential oils ranged from $\beta$-Caryophyllene $(1.9 \%)$ to Carvacrol $(19.9 \%)$ in thyme; cisThujone $(2.3 \%)$ to Camphenilone $(25.2 \%)$ in sage and $\alpha$-terpineol $(2.5 \%)$ to Comphor $(34.7 \%)$ in rosemary. The zone of inhibition in essential oils which was obtained from thyme against Ascochyta rabiei was $20 \mathrm{~mm}$, sage (17 $\mathrm{mm}$ ) and rosemary $(19 \mathrm{~mm})$. The minimum inhibition of essential oils from thyme leaves was $125 \pm 0.02 \mathrm{mg} / \mathrm{ml}$, sage $(250 \pm 0.01 \mathrm{mg} / \mathrm{ml})$ and rosemary $(250 \pm 0.02 \mathrm{mg} / \mathrm{ml})$. The essential oils from thyme, sage and rosemary have bioactive compounds that have antifungal properties against Ascochyta rabiei.
\end{abstract}

Keywords: Antagonism; Ascochyta rabiei; Chickpea; Rosemary; Sage; Thyme

\section{Introduction}

Chick peas (Cicer arietinum) have been described as an immensely nutritious pulse crop [1]. Its popularity lies in its high protein content which has led to the plant been branded as poor man's meat [2]. The plant thieves well in arid and semi-arid environmental conditions [3]. Chickpea is produced majorly by countries such as India, Turkey, Pakistan, Iran and Mexico [4]. Pakistan is one of the leading countries in production of the crop in the world. In Kenya the crop ranks third in cultivation after common bean and peas [5]. However, the acreage production of chickpea is very low in Kenya comparing to other countries throughout the world [6]. Regardless of the increasing demand of cheap protein sources, chickpea production is low with a world production of $0.8 \mathrm{t} / \mathrm{ha}$ [7]. About ninety percent losses in the yield occur due to root based diseases and pathogenic fungi such as ascomyceta blight [1]. Chickpea production is greatly influenced by root based pathogens in many countries of the world like India, Pakistan, Tunisia, Spain, Iran, Nepal and Burma [8].

Root infecting pathogenic fungi includes mainly Fusarium oxysporum fsp. ciceris, Macrophomina phaseolina, Fusarium solani, Rhizoctonia solani and Phythium ultimum [9]. These fungal pathogens are most prevalent because they produce spores which can persist in the environment without the host plant for more than six years [10]. Studies carried out elsewhere reported that ascomycota blight is responsible for $10 \%-15 \%$ yield losses in chickpea while black root rot damaged 60\%-70\%. Dry root rot caused by Macrophomina phaseolina damage over 500 host plant species of the tropical and temperate regions of the world [10].

Currently, many fungi including Ascochyta rabiei in chickpea have developed resistance to conventional anti-fungicides been used to day [11]. One of the remedies to the resistance is seeking for natural solutions to the problem such as the use of essential oils from different oil producing plants [12].

The term "essential oil" (Eos) was used for the first time in the $16^{\text {th }}$ century by Paracelsus von Hohenheim, who used it to refer to the effective component of a drug as "Quinta essential" [13]. However, the first use of essential oils for therapeutic reasons was found in a document known as Ebers papyrus [14]. The document listed more than 800 EOs remedies and treatments of various diseases [15]. Myrrh was a favorite ingredient, often mixed with honey and other herbs, because of its high potential of inhibiting bacterial growth [16].

According to Fernandez DJ et al. essential oils are volatile oils that are complex mixtures of volatile constituents. They are synthesized by plants whose contents are made of at least two related groups which include terpenes and terpenoids and aromatic and aliphatic constituents, all of which have low molecular weight $[17,18]$. 
Citation: Waithaka PN, Gathuru EM, Githaiga B, Mwaringa JD (2018) Control of Ascochyta blight of Chickenpea using Essential Oils from Thyme (Thymus vulgaris), Sage (Salvia officinalis L.) and Rosemary (Rosmarinus officinalis L.) Plants. J Antimicrob Agents 4: 176. doi: $10.4172 / 2472-1212.1000176$

Page 2 of 7

Thymus sp. is a well-known plant with aromatic characteristics which has been used since ancient times as a spice and herbal medicine [19]. Gharbi $S$ et al. reported that essential oils from thyme (Thymus zygis L.) had a great inhibitory effect on Botrytis cinerea spore germination when compared with essential oils from other plants $[20,21]$.

Another source of essential oils that has been exploited for a long time is members of the family Cyperaceae (sages) [20]. The sages are ubiquitous, but require experience to recognize because of their closeness to the grass family [21]. observed that four-fifths of the sedge plants do very well in damp or wet places, while one-fifth is found in drier regions, such as savannah grassland and sandy places including sand-dunes [21,22].

On the other hand, rosemary (Rosmarinus officinalis L.) originated from Southern Europe [23]. The plant has high antimicrobial and antioxidant properties [24]. Besides, the plant is used as a food flavoring agent because of its desirable aroma [25]. Egamberdieva D et al. reported that rosemary plants are rich sources of phenolic compounds with high antimicrobial activity against both Grampositive and Gram-negative bacteria [26,27].

The aim of this study was to investigate the antifungal properties of essentials oils from thyme, sage and rosemary plant against Ascochyta rabiei.

\section{Materials and Methods}

\section{The study area}

The study was conducted at Egerton University, main campus Njoro in Kenya. Egerton University is located in Njoro Sub County with coordinates as $0^{\circ} 23^{\prime}$ south, $35^{\circ} 35^{\prime}$ and altitude of $2000 \mathrm{~m}$ above sea level. Temperatures range between $17^{\circ} \mathrm{C}-22^{\circ} \mathrm{C}$ while the average annual rainfall is $1000 \mathrm{~mm} \mathrm{[28].}$

\section{Collection of infected plant samples}

One hundred and fifty samples of infected chick pea plant were randomly collected from field seven in Egerton University. The samples were weighed before being placed in sterile plastic bags, before storage in a refrigerator until mycological analysis.

\section{Collection of thyme, sage and rosemary plant samples}

A pair of secateurs was used in cutting rosemary, sage and rosemary samples from the host plants growing in Egerton University (Figure 1). The samples were separately placed in plastic containers to prevent drying and escaping of the volatile oils from the specimen. The samples were stored in a deep freezer at $4^{\circ} \mathrm{C}$ until processing.
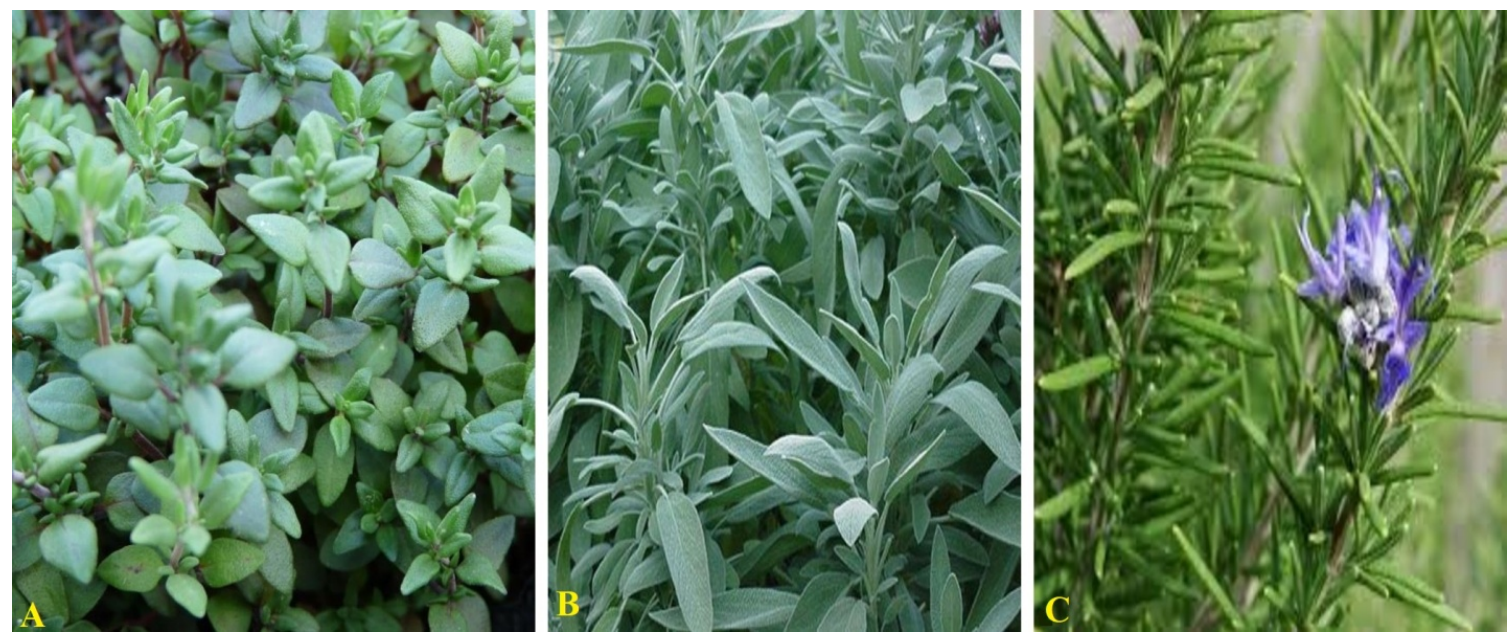

Figure 1: Plant samples collected from thyme (A), sage (B) and rosemary (C).

\section{Isolation of the fungi}

The fungal pathogens were cultured in Potato Dextrose (Oxoid, Basingstoke, UK). The chickpea plant samples were placed in $10 \%$ sodium hypochlorite for 2 minutes before rinsing using sterile water. The chickpea plant samples were blot dried using previously sterilized Whatman filter papers and directly plated on Potato Dextrose Agar (PDA) media. The plates were incubated at a $28^{\circ} \mathrm{C}$ for up to 7 days. The fungal colonies were sub-cultured separately in PDA till pure cultures were obtained. The pure cultures were separately stored in PDA slants at $4^{\circ} \mathrm{C}$ until further processing. Isolation frequency (IF) for each fungus was determined and expressed as percent [29].

\section{Cultural and morphological characterization of fungal pathogens}

Identification of the fungal pathogens was carried out using cultural, morphological characteristics and fungi identification keys [30]. The cultural characteristics used in identification were colour of the colony, size and speed of growth in the culture medium. Morphological features considered were the size of the conidiophores, hyphae characteristics and elevation of the philiades.

\section{Extraction of essential oils from thyme, sage and rosemary plant samples}

A sample of $400 \mathrm{~g}$ of fresh thyme, sage and rosemary leaves were separately loaded into $2 \mathrm{~L}$ round bottom flask containing $1.5 \mathrm{~L}$ of water 
Citation: Waithaka PN, Gathuru EM, Githaiga B, Mwaringa JD (2018) Control of Ascochyta blight of Chickenpea using Essential Oils from Thyme (Thymus vulgaris), Sage (Salvia officinalis L.) and Rosemary (Rosmarinus officinalis L.) Plants. J Antimicrob Agents 4: 176. doi: $10.4172 / 2472-1212.1000176$

Page 3 of 7

and placed on a heating mantle having power of $450 \mathrm{~W}$ and timed. The samples were boiled with water to release the oil within the leaves. The volatile oils evaporated along with the water into the condenser connected to a flask at $100^{\circ} \mathrm{C}$. The condensed steam and oils were collected in a separating funnel after which oil and water were separated. The water was drained off gently and the oils were separately collected in a $10 \mathrm{ml}$ measuring cylinder and measured after every 20 minutes for a period of 3 hours. The traces of water in the essential oils were removed by adding 1 gram of magnesium sulphate in the oil as a drying agent [31].

\section{Sensitivity test of Ascochyta rabiei to essential oils extracted from thyme, sedge and rosemary}

The antifungal activity of the essential oils was determined using agar well technique [3]. Wells $8 \mathrm{~mm}$ in diameter were made in PDA previously inoculated with Ascochyta rabiei. Separately, the essential oils from thyme, sage and rosemary plants were aseptically added using a micropipette. The petri dishes were placed in a refrigerator for
$2 \mathrm{~h}$ to give the essential oils time to diffuse. The petri dishes were incubated at $27^{\circ} \mathrm{C}$ for 5 days. Antagonism was measured by determination of the size of the inhibition zone in millimeters.

\section{Data analysis}

Data analysis was carried out using Microsoft excel spreadsheet and Statistical Package for Social Sciences (SPSS) version 17.0 software. Pearson's correlation was used to determine the relationship between heating period and yield of essential oils while t-test was used in comparing yield of essential oils in rosemary and eucalyptus.

\section{Results}

\section{Isolation of fungal pathogens from chickpea plant}

Cultural and morphological characteristics of the fungal isolates are presented in Table 1.

\begin{tabular}{|c|c|c|c|}
\hline Fungal pathogens & Cultural characteristics & Morphological characteristics & Frequency $(\%)$ \\
\hline Ascochyta rabiei & Large pink, rapidly growing cottony colonies. & $\begin{array}{l}\text { The conidia were hyaline, rounded at both ends and } \\
\text { occasionally two-celled under compound microscope. }\end{array}$ & 50 \\
\hline Alternaria spp. & $\begin{array}{l}\text { Large, brown colonies almost filling the whole } \\
\text { plate. }\end{array}$ & Septate branched hyphae with brown conidia. & 45 \\
\hline Fusarium spp. & $\begin{array}{l}\text { Rapidly growing wooly to cottonly lemon and } \\
\text { yellow. }\end{array}$ & Multicellular distinctive sickle shaped macro conidia. & 22 \\
\hline Colletotrichum spp. & Large cottony growth, pink pigmented. & $\begin{array}{l}\text { Conidia are one-celled, ovoid to oblong, slightly curved } \\
\text { at one. }\end{array}$ & 17 \\
\hline Penicillium spp. & $\begin{array}{l}\text { Large fluffy white colonies almost covering the } \\
\text { whole surface. }\end{array}$ & $\begin{array}{l}\text { Non-septate branched hyphal enlarge at the apex to } \\
\text { form cornidophorex they produce brownish black } \\
\text { conidia in chains. }\end{array}$ & 16 \\
\hline
\end{tabular}

Table 1: Examples of pheromone-guided antimicrobial peptides (PG-AMP).

The prevalence of Ascochyta rabiei (Figure 2) in the plant samples from chickpea was $50 \%$. The most prevalent fungal pathogens were Alternaria spp. (45\%), Fusarium spp. (22\%), Coletotrichum spp. (17\%), and the least was Penicillium spp. (16\%).

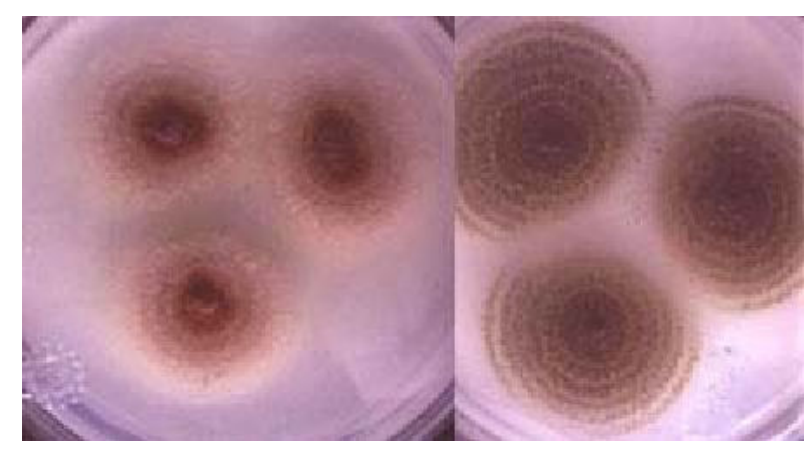

Figure 2: Pure cultures of Ascochyta rabiei growing on PDA.

\section{Extraction of essential oils}

Essentials oils from thyme, sage and rosemary had different colours (Figure 3).

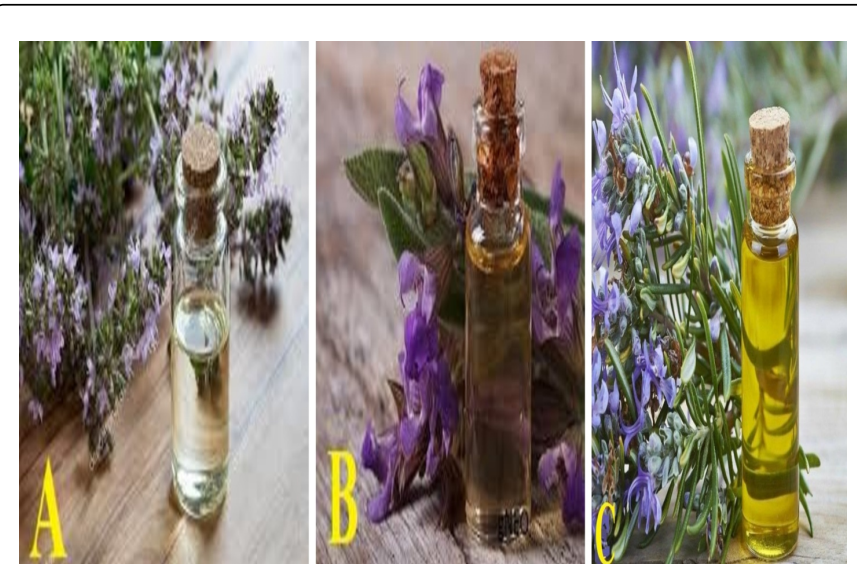

Figure 3: Essential oil from thyme (A), sage (B) and rosemary (C). 
Citation: Waithaka PN, Gathuru EM, Githaiga B, Mwaringa JD (2018) Control of Ascochyta blight of Chickenpea using Essential Oils from Thyme (Thymus vulgaris), Sage (Salvia officinalis L.) and Rosemary (Rosmarinus officinalis L.) Plants. J Antimicrob Agents 4: 176. doi: $10.4172 / 2472-1212.1000176$

Page 4 of 7

The yield of essential oils varied from $0.6 \%$ after the samples were heat for 20 minutes to $4.5 \%$ after heating for 180 minutes in thyme (Table 2). On the other hand, the percentage yield in sage plant ranged from $0.1 \%$ after the samples were heat for 20 minutes to $3.5 \%$ after heating for 180 minutes. However, the yield of essential oils from rosemary varied from $0.1 \%$ after heating the samples for 20 minutes to $2.2 \%$ after the samples were heat for 140 minutes.

\begin{tabular}{|c|c|c|c|c|c|}
\hline Plant & $\begin{array}{l}\text { Weight } \\
\text { (g) }\end{array}$ & $\begin{array}{l}\text { Distilled } \\
\mathrm{H}_{2} \mathrm{O} \text { (L) }\end{array}$ & $\begin{array}{l}\text { Heating time } \\
\text { (minutes) }\end{array}$ & $\begin{array}{l}\text { Temperature } \\
\left({ }^{\circ} \mathrm{C}\right)\end{array}$ & $\begin{array}{l}\text { Yield } \\
(\%)\end{array}$ \\
\hline \multirow{9}{*}{ Thyme } & 400 & 1.5 & 20 & 100 & 0.6 \\
\hline & 400 & 1.5 & 40 & 100 & 1 \\
\hline & 400 & 1.5 & 60 & 100 & 1.7 \\
\hline & 400 & 1.5 & 80 & 100 & 2 \\
\hline & 400 & 1.5 & 100 & 100 & 2.8 \\
\hline & 400 & 1.5 & 120 & 100 & 3 \\
\hline & 400 & 1.5 & 140 & 100 & 3.2 \\
\hline & 400 & 1.5 & 160 & 100 & 4.1 \\
\hline & 400 & 1.5 & 180 & 100 & 4.5 \\
\hline \multirow{9}{*}{ Sage } & 400 & 1.5 & 20 & 100 & 0.2 \\
\hline & 400 & 1.5 & 40 & 100 & 0.4 \\
\hline & 400 & 1.5 & 60 & 100 & 0.6 \\
\hline & 400 & 1.5 & 80 & 100 & 1.1 \\
\hline & 400 & 1.5 & 100 & 100 & 1.7 \\
\hline & 400 & 1.5 & 120 & 100 & 2 \\
\hline & 400 & 1.5 & 140 & 100 & 2.8 \\
\hline & 400 & 1.5 & 160 & 100 & 3 \\
\hline & 400 & 1.5 & 180 & 100 & 3.5 \\
\hline \multirow{9}{*}{ Rosemary } & 400 & 1.5 & 20 & 100 & 0.1 \\
\hline & 400 & 1.5 & 40 & 100 & 0.6 \\
\hline & 400 & 1.5 & 60 & 100 & 0.4 \\
\hline & 400 & 1.5 & 80 & 100 & 1.2 \\
\hline & 400 & 1.5 & 100 & 100 & 1.9 \\
\hline & 400 & 1.5 & 120 & 100 & 1 \\
\hline & 400 & 1.5 & 140 & 100 & 2.2 \\
\hline & 400 & 1.5 & 160 & 100 & 2 \\
\hline & 400 & 1.5 & 180 & 100 & 1.5 \\
\hline
\end{tabular}

Table 2: Yield of essential oils from rosemary, sage and thyme.

The weights of the plant samples, volume of distilled water and the heating temperature were maintained constant at $400 \mathrm{~g}, 1.5 \mathrm{~L}, 100^{\circ} \mathrm{C}$ respectively. There was a relationship between heating time and yield of essential oils in rosemary $(r=0.99)$ and leaves $(r=0.99)$. Conversely, there was no significant difference in the percentage yield of essential oils thyme, sage and rosemary $(\mathrm{P}=0.057)$.

\section{Constituents of essential oils from leaves of thyme plant}

The percentage composition of alpha pinene in thyme leaves was $11.3 \%$, camphene $(2.6 \%)$, beta pinene $(9.5 \%)$, para cymene $(11.2 \%)$, linalool (15.3\%), borneol (10.9\%), beta caryophyllene (1.9\%), thymol (13.2\%), carvacrol (19.9\%), alpha terpinene (5.6\%) (Table 3).

There was no significant difference in the percentage composition of the different compounds in the essential oils extract from thyme, sage and rosemary $(\mathrm{F}=0.75, \mathrm{P}=0.48)$.

\begin{tabular}{|l|l|}
\hline Compound & Composition (\%) \\
\hline Alpha Pinene & 11.3 \\
\hline Camphene & 2.6 \\
\hline Beta Pinene & 9.5 \\
\hline Para Cymene & 11.2 \\
\hline Linalool & 15.3 \\
\hline Borneol & 10.9 \\
\hline Beta Caryophyllene & 1.9 \\
\hline Thymol & 13.2 \\
\hline Carvacrol & 19.9 \\
\hline Alpha Terpinene & 5.6 \\
\hline
\end{tabular}

Table 3: GC-MS analysis of essential oils from thyme leaves.

\section{Constituents of essential oils from leaves of sage plant}

The percentage composition of $\alpha$-thujene in essential oil from sage leaves was $23.2 \%$, $\alpha$-pinene $(15.7 \%)$, camphene $(10.4 \%), \beta$-pinene (9.6\%), myrcene (15.8\%), p-cymene (12.2\%), 1,8-cineole (13.9\%), camphenilone (25.2\%), cis-thujone (2.3\%), trans-thujone (4.1\%) (Table 4).

\begin{tabular}{|l|l|}
\hline Compound & Composition (\%) \\
\hline a-Thujene & 23.2 \\
\hline a-pinene & 15.7 \\
\hline Camphene & 10.4 \\
\hline -Pinene & 9.6 \\
\hline Myrcene & 15.8 \\
\hline p-Cymene & 12.2 \\
\hline 1,8-Cineole & 13.9 \\
\hline Camphenilone & 25.2 \\
\hline cis-Thujone & 2.3 \\
\hline trans-Thujone & 4.1 \\
\hline
\end{tabular}

Table 4: GC-MS analysis of essential oils from sage (Salvia officinalis L.) leaves. 
Citation: Waithaka PN, Gathuru EM, Githaiga B, Mwaringa JD (2018) Control of Ascochyta blight of Chickenpea using Essential Oils from Thyme (Thymus vulgaris), Sage (Salvia officinalis L.) and Rosemary (Rosmarinus officinalis L.) Plants. J Antimicrob Agents 4: 176. doi: $10.4172 / 2472-1212.1000176$

Page 5 of 7

\section{Constituents of essential oils from leaves of rosemary plant}

The percentage composition of comphor in essential oil from sage leaves was $34.7 \%$, $\alpha$-pinene (21.6\%), 1,8-cineole (14.4\%), camphene $(8.6 \%)$, borneol $(7.7 \%), \beta$-pinene $(7.5 \%)$, verbenone $(5.8 \%), \beta$ caryophyllene (5.1\%), limonene (3.8\%), $\alpha$-terpineol (2.5\%) (Table 5).

\begin{tabular}{|c|c|}
\hline Compound & Composition (\%) \\
\hline Comphor & 34.7 \\
\hline a-pinene & 21.6 \\
\hline 1,8-cineole & 14.4 \\
\hline camphene & 8.6 \\
\hline Borneol & 7.7 \\
\hline$\beta$-pinene & 7.5 \\
\hline Verbenone & 5.8 \\
\hline$\beta$-caryophyllene & 5.1 \\
\hline Limonene & 3.8 \\
\hline a-terpineol & 2.5 \\
\hline
\end{tabular}

Table 5: GC-MS analysis of essential oils from rosemary (Rosmarinus officinalis $L$.) leaves.

\section{Sensitivity of Ascochyta rabiei to essential oils from thyme, sage and rosemary}

The zone of inhibition of essential oils obtained from thyme against Ascochyta rabiei was $20 \mathrm{~mm}$, sage $(17 \mathrm{~mm})$ and rosemary $(19 \mathrm{~mm})$ (Table 6).

\begin{tabular}{|l|l|}
\hline Essential oil & Zone of inhibition $(\mathbf{m m})$ \\
\hline Thyme & 20 \\
\hline Sage & 17 \\
\hline Rosemary & 19 \\
\hline
\end{tabular}

Table 6: Sensitivity of the fungal pathogens to the extracted essential oils from thyme sage and rosemary.

\section{Minimum inhibitory concentration (MIC) and minimum fungicidal concentration (MFC) of Ascochyta rabiei to essential oils from thyme, sage and rosemary}

The minimum inhibition of essential oils from thyme leaves was 125 $\pm 0.02 \mathrm{mg} / \mathrm{ml}$, sage $(250 \pm 0.01 \mathrm{mg} / \mathrm{ml})$ and rosemary $(250 \pm 0.02$ $\mathrm{mg} / \mathrm{ml}$ ) (Table 7).

\begin{tabular}{|l|l|l|}
\hline Essential oil & MIC inhibition $(\mathbf{m g} / \mathbf{m l})$ & MFC $(\mathbf{m g} / \mathbf{m l})$ \\
\hline Thyme & $125 \pm 0.02$ & $125 \pm 0.02$ \\
\hline Sage & $250 \pm 0.01$ & $250 \pm 0.01$ \\
\hline Rosemary & $250 \pm 0.02$ & $250 \pm 0.02$ \\
\hline
\end{tabular}

Table 7: MIC and MFC of essential oils from thyme, sage and rosemary plant.
In addition, the minimum fungicidal concentration of essential oils from thyme was $(125 \pm 0.02 \mathrm{~mm} / \mathrm{ml})$, sage $(250 \pm 0.01)$ and rosemary $(250 \pm 0.02)$. The minimum inhibition concentration of in essential oils from thyme tree leaves, sage and rosemary were equal to the minimum fungicidal concentration.

\section{Discussion}

The most common fungal pathogens in chickpea isolated in the current study were Ascochyta rabiei (50\%), Alternaria sp. (45\%), Fusarium sp. (22\%), Coletrotrichum sp. (17\%) and Penicillium sp. (16\%). These results differed with those of a previous study carried out in China [17]. This can be attributed to differences in the environment in which the plants were growing. In addition [21] obtained results that differed with those of the current study. Further Eljounaidi K et al. explained that the spore content in the soil in which chickpea are growing greatly influences the fungal isolates obtained from plants growing in those areas [30].

However, the percentage yield of essential oils from leaves of thyme plant obtained in the current study concurred with a previous study carried out in Jordan by Abu-Darwish MS et al. [32]. These may be attributed to the species of thyme tree from which the essentials oils were extracted. In addition, the percentage yield of essential oils obtained from sage plant in this study differed with those obtained by Hamad YK et al. [33]. This may be attributed to the nutrient level of the soils in which the plant is growing in. Bernardes WA et al. explained that the soil nutrient level of a given area influences synthesis of essential oils in sage plant [34].

The percentage yield of essential oils from rosemary obtained from this study concurred with a study carried out by Moghtader $M$ et al. [35]. This may be attributed to similarity of the species of rosemary that were being studied by Iqbal SM et al. [14]. Further Aljabeili HS et al. explained that the method of extraction of essential oils affects production of essential oils in Rosemary spp. [36].

The constituents of essential oils obtained from thyme leaves concurred with a previous study carried out in Pakistan [37]. Witkowska DI et al. asserted that the biochemical pathways used by thyme plant greatly influences the composition of essential oils produced [11]. The compounds obtained from essential oils of sage leaves in the present study agreed with a previous study carried out in India. This may be attributed to similarities in the study areas [38].

However, the constituents of essential oils from rosemary slightly differed with previous studies carried out in Brazil [39]. According to Bassolé IH et al. the species of rosemary from which the essential oils were obtained may have contributed to the observed results [40].

On the other hand, the zones of inhibition of the extracted essential oils from thyme, sage and rosemary on Ascochyta rabiei disagreed with a previous study by Pandey AK et al. [41]. This may be attributed to the type of solvents used to extract the essential oils [42]. Besides the minimum inhibition concentration (MIC) and minimum fungicidal concentration (MFC) obtained in the present study disagreed with a previous study [7]. This may be attributed to variations in the compounds present in the essential oils extracted [4]. In addition, MIC and MFC obtained in this study were equal. This suggested that the essential oils were fungicidal and not fungistatic. 
Citation: Waithaka PN, Gathuru EM, Githaiga B, Mwaringa JD (2018) Control of Ascochyta blight of Chickenpea using Essential Oils from Thyme (Thymus vulgaris), Sage (Salvia officinalis L.) and Rosemary (Rosmarinus officinalis L.) Plants. J Antimicrob Agents 4: 176. doi: $10.4172 / 2472-1212.1000176$

Page 6 of 7

\section{Conclusion}

Isolation of fungal pathogens from chickpea was carried out. Essential oils were extracted from thyme, sage and rosemary and their active ingredients determined. In addition, sensitivity test of the extracted essential oils to Ascochyta rabiei was carried out followed by determination of their MIC and MFC.

\section{Recommendations}

There is need to test the sensitivity of other fungal and bacterial pathogens to the extracted essential oils. Mass production of essential oils from thyme, sage and rosemary need to be carried out.

\section{References}

1. Hossain F, Follett P, Dang V, Harich M, Salmieri S, et al. (2016) Evidence for synergistic activity of plant-derived essential oils against fungal pathogens of food. Food Microbiol 53: 24-30.

2. Mehdi N, Maryam H, Mohammad BHN, Reza F (2017) Synergistic effects of some essential oils against fungal spoilage on pear fruit. Int J Food Microbiol 257: 285-294.

3. Bhanu P, Akash K, Akanksha S, Shashi Y, Arti S, et al. (2016) Antifungal, antiaflatoxin and antioxidant activity of plant essential oils and their in vivo efficacy in protection of chickpea seeds. J Food Quality 39: 36-44.

4. Ali B, Al-Wabel NA, Shams S, Ahamad A, Khan SA, et al. (2015) Essential oils used in aromatherapy: A systemic review. Asian Pac J Trop Biomed 5: 601-611.

5. Zeedan GSG, Abdalhamed AM, Ottai ME, Abdelshafy S, Abdeen E (2014) Antimicrobial, antiviral activity and GC-MS analysis of essential oil extracted from Achillea fragrantissima plant growing in Sinai Peninsula, Egypt. J Microb Biochem Tech 8: 1-21.

6. Tamara B, Dženita S, Jela G (2014) Antimicrobial activity of some essential oils and major constituents of essential oils. Acta Med Academ 35: 19-22.

7. Mustafa HR (2014) Antimicrobial activity of plant essential oils against the growth of Escherichia coli. IOSR J Pharm 3: 1-6.

8. Mallappa KS, Mohd SA, Uma RS (2016) Antimicrobial properties of plant essential oils against human pathogens and their mode of action. Evid Based Complement Alternat Med 30: 12-29.

9. Amini M, Safaie N, Salmani MJ, Shams-Bakhsh M (2012) Antifungal activity of three medicinal plant essential oils against some phytopathogenic fungi. Trakia J Sci 10: 1-8.

10. Ilić BS, Kocić BD, Ćirić VM, Cvetković OG, Miladinović DL (2015) An in vitro synergistic interaction of combinations of Thymus glabrescens essential oil and its main constituents with chloramphenicol. Sci World J 11: 55-79.

11. Witkowska DI, Sowińska JI, Żebrowska JP, Mituniewicz EI (2016) The antifungal properties of peppermint and thyme essential oils misted in broiler houses. Braz J Poultry Sci 18(4): 629-638.

12. Luca R, Laura O (2014) Activity of tea tree (Melaleuca alternifolia, Cheel) and thyme (Thymus vulgaris, L.) essential oils against some pathogenic seed borne fungi. J Essent Oil Res 23: 1-5.

13. Abdullah BH, Hatem SF, Jumaa W (2015) A comparative study of the antibacterial activity of clove and rosemary essential oils on multidrug resistant bacteria. UK J Pharm Biosci 3: 18-22.

14. Iqbal SM, Ghafoor A, Ayub N, Ahmad Z (2014) Pathogenic diversity in Ascochyta rabiei isolates collected from Pakistan. Pak J Bot 36: 429-437.

15. Dolar FR (2017) Toxin production and DNA sequence analysis of Turkish isolates of Ascochyta rabiei, the causual agent of ascochyta blight in Chickpea. J Turk Phytopath 39: 31-37.

16. Narayan OP, Verma N, Singh AK, Oelmuller R, Kumar M, et al. (2017) Piriformospora indica participate in defense against the pathogen Botrytis cinerea. Sci rep 7: 13553.
17. Fernández, DJ, Landa BB, Kang S, Jiménez-Díaz RM, Navas-Cortés JA (2013) Quantitative and microscopic assessment of compatible and incompatible interactions between chickpea cultivars and Fusarium oxysporum f. sp. ciceri Races. Plos one 8: 234-256.

18. Samia G, Noureddine K, Mostafa C, Merbrouk K, Eddine K (2015) Comparison of Ascochyta rabiei isolates from cultural characteristics and isozyme. Int J Biosci 6: 30-39.

19. Elliott VL, Taylor PWJ, Ford R (2014) Pathogenic variation within the 2009 Australian Ascochyta rabiei population and implications for future disease management strategy. Australas. Plant Pathol 40: 568-574.

20. Gharbi S, Karkachi N, Kihal M, Henni J (2015) Carbon sources and pH effect on pectinolytic activity production by Ascochyta rabiei isolated from chickpea (Cicer arietinum L.) in West Algeria. Afr J Microbiol Res 7: 3483-3488.

21. Benzohra IE, Bendahmane BS, Labdi M, Benkada MY (2016) Sources of resistance in chickpea germplasm to three pathotypes of Ascochyta rabiei (Pass.) Labr. in Algeria. World Appl Sci J 6: 873-878.

22. Karkachi N, Gharbi S, Kihal M, Henni JE (2017) Study of pectinolytic activity of Fusarium oxysporum f.sp albedinis agent responsible for bayoud in Algeria. Int J Agro Agric Res 5: 40-45.

23. Sarwar N, Ashfaq S, Akhtar KP, Jamil FF (2015) Biological pathotyping and RAPD analysis of Ascochyta rabiei from various chickpea growing areas of Pakistan. J Anim Plant Sci 23: 882-887.

24. Lamichhane JR, Saccardo F, Crinò P (2016) Response of chickpea germplasms to new Italian isolates of Ascochyta rabiei. Tunis J Plant Prot 7: 19-25.

25. Djamel M, Boubekeur SB, Mokhtar YB, Martina R (2015) Physiological characterization of Ascochyta rabiei (Pass.) Lab. Isolated from diseased chickpea fields in six regions of Northwestern Algeria. AmericanEurasian J Agric Environ Sci 15: 1136-1146.

26. Egamberdieva D, Wirth SJ, Shurigin VV, Hashem A, Abd EF (2017) Endophytic Bacteria improve plant growth, symbiotic performance of chickpea (Cicer arietinum L.) and induce suppression of root rot caused by Fusarium solani under salt stress. Front Microbiol 8: 1887.

27. Ahmad P, Hashem, A, Abd EF, Alqarawi AA, John R, et al. (2015) Role of Trichoderma harzianum in mitigating $\mathrm{NaCl}$ stress in Indian mustard (Brassica juncea $L$ ) through antioxidative defense system. Front Plant Sci 6: 868.

28. Egamberdieva D, Li L, Lindström K, Räsänen LA (2016) A synergistic interaction between salt tolerant Pseudomonas and Mezorhizobium strains improves growth and symbiotic performance of liquorice (Glycyrrhiza uralensis Fish.) under salt stress. Appl Microbiol Biotechnol 100: 2829-2841.

29. Egamberdieva D, Shurigin V, Gopalakrishnan S, Sharma R (2014) Growth and symbiotic performance of chickpea (Cicer arietinum) cultivars under saline soil conditions. J Biol Chem Res 31: 333-341.

30. Eljounaidi K, Lee SK, Bae H (2016) Bacterial endophytes as potential biocontrol agents of vascular wilt diseases-review and future prospects. Biol Control 103: 62-68.

31. Gond SK, Bergen MS, Torres MS, White JF (2015) Endophytic Bacillus spp. produce antifungal lipopeptides and induce host defence gene expression in maize. Microbiol Res 172: 79-87.

32. Abu-Darwish MS, Cabral C, Ferreira IV, Gonçalves MJ, Cavaleiro C, et al. (2014) Essential oils of common sage (Salvia officinalis L.) from Jordan: assessment of safety in mammalian cells and its antifungal and antiinflammatory potential. Biomed Res Int 53: 89-99.

33. Hamad YK, Fahmi MM, Zaitoun FM, Ziyada SM (2015) Role of essential oils in controlling fungi that cause decline disease of Guava. Int J Pure App Biosci 3: 143-151.

34. Bernardes WA, Lucarini R, Tozatti MG, Flauzino LG, Souza MG, et al. (2014) Antibacterial activity of the essential oil from Rosmarinus officinalis and its major components against oral pathogens. Z Naturforsch C 65: 588-593.

35. Moghtader M, Salari H, Farahmand A (2014) Evaluation of the antifungal effects of rosemary oil and comparison with synthetic borneol and 
Citation: Waithaka PN, Gathuru EM, Githaiga B, Mwaringa JD (2018) Control of Ascochyta blight of Chickenpea using Essential Oils from Thyme (Thymus vulgaris), Sage (Salvia officinalis L.) and Rosemary (Rosmarinus officinalis L.) Plants. J Antimicrob Agents 4: 176. doi: $10.4172 / 2472-1212.1000176$

Page 7 of 7

fungicide on the growth of Aspergillus flavus. J. Ecol. Nat. Environ 3: 210-214.

36. Aljabeili HS, Barakat H, Abdel-Rahman HA (2018) Chemical composition, antibacterial and antioxidant activities of thyme essential Oil (Thymus vulgaris). Food Nutrition Sci 9: 433-446.

37. Tiwalade AA, Peter AE, Elizabeth AO (2014) Investigating the phytochemicals and antimicrobial properties of three sedge (Cyperaceae) species. Not Sci Biol 6: 276-281.

38. Porte A, Godoy RLO, Maia-Porte LH (2014) Chemical composition of sage (Salvia officinalis L.) essential oil from the Rio de Janeiro State (Brazil). Rev Bras Pl Med Campinas 15: 438-441.

39. Aziza KG, Haiko H, Artur SJ, Simone MS (2014) Rosemary (Rosmarinus officinalis)-A study of the composition, antioxidant and antimicrobial activities of extracts obtained with supercritical carbon dioxide. Ciênc Tecnol 28: 463-469.

40. Bassolé IH, Juliani HR (2012) Essential oils in combination and their antimicrobial properties. Molecules 17: 3989-4006.

41. Pandey AK, Kumar P, Singh P, Tripathi NN, Bajpai VK (2017) Essential Oils: Sources of antimicrobials and food preservatives. Front Microbiol 7: 2161.

42. Flores CR, Pennec A, Nugier-Chauvin C, Daniellou R, Herrera-Estrella L, et al. (2014) Chemical composition and antibacterial activity of essential oils extracted from plants cultivated in Mexico. J Mex Chem Soc 58: 452-455. 